\title{
QISHASH LAW AND HUMAN RIGHTS
}

\author{
Anas Rohman \\ Unwahas \\ anasrohman@unwahas.ac.id
}

\begin{abstract}
The purpose of Islamic criminal law is to preserve the soul, mind, property of society in general, and offspring. Therefore, the position of Islamic criminal law is very important in social life. This is because four of the five objectives of the Shari'a mentioned above can only be achieved by complying with the provisions of Islamic criminal law, and two of them are sequentially with the provisions of Islamic civil law, namely property and offspring, while the mind and soul are solely preserved by the provisions of Islamic criminal law. . The purpose of Islamic criminal law is to preserve the soul, mind, property of the community in general, and offspring. Therefore, the position of Islamic criminal law is very important in social life. This is because four of the five objectives of the Shari'a mentioned above can only be achieved by complying with the provisions of Islamic criminal law, and two of them are sequentially with the provisions of Islamic civil law, namely property and offspring, while the mind and soul are solely preserved by the provisions of Islamic criminal law. .
\end{abstract}

\section{Password : Qishash Law, Human Rights}

\section{A. INTRODUCTION}

Human nature as a social being requires other humans to fulfill their various needs. On the one hand, the diversity of interests between people in a group can be fulfilled peacefully, on the other hand this diversity can also lead to conflict if the procedure for fulfilling these interests is carried out without any balance so that it will violate the rights of others.

Lately, some of us may have heard a lot of news about protests and criticism from various elements of society about the implementation of the death penalty. Most of those who protest against the death penalty think that the death penalty is a practice of violating human rights; namely the right to life. They think that by punishing someone to death, we have clearly deprived that person of their right to life. However, in terms of law and justice, the death penalty is a fair legal practice. The opinion that is often put forward in defense of the execution of the death penalty is that the convicted person deserves the death penalty. So we can see that there are two opposing sides. One is the Human Rights side, while the other side is justice. Therefore, in this paper, the 
author will try to make a review of the complexity of the relationship that exists between the death penalty and human rights.

\section{B. DISCUSSION}

\section{Provisions of Qishash}

Every criminal act (delik, jarimah) must have a legal sanction ('uqubat) imposed on the perpetrator (al-Jany), whether in the form of the punishment of hell, qishas, diyat, had, expiation and fidyah, where the executor of the sanction is Allah himself, the ruler or the person himself, both the place of its execution in this world and the hereafter ${ }^{1}$. A person who commits a crime must also meet the conditions, namely: reasonable, old enough, have free will ${ }^{2}$.

The crime of murder and persecution, is a jarimah Qishash whose punishment is an individual right. The difference in principle between the rights of God and the rights of society and the rights of the individual lies in the matter of forgiveness. The punishment of qishash which is an individual right has the effect of amnesty that can be given by the victim or his family.

Based on the purpose of Islamic law, it can be formulated that the purpose of Islamic criminal law is to preserve the soul, mind, property of society in acommon, and hereditary. Therefore, the position of Islamic criminal law is very important in social life ${ }^{3}$. This is because four of the five objectives of the Shari'a mentioned above can only be achieved by complying with the provisions of Islamic criminal law, and two of them are sequentially with the provisions of Islamic civil law, namely property and offspring, while the mind and soul are solely preserved by the provisions of Islamic criminal law.

Qishash comes from the word اص which means to cut or comes from the word Iqtassan which means to follow, namely following the actions of the criminal as revenge for his actions. According to syara' qishash is a balanced punishment for the perpetrators of murder or destruction or removal of the function of another person's body which is done intentionally.

Intentional killing without any justifiable reason is haraam and is a major sin. Allah SWT says:

\footnotetext{
${ }^{1}$ Haliman, Hukum Pidana Syari'at Islam Menurut Ahlus Sunnah, (Jakarta: Bulan Bintang. 1970), hlm. 67

2 Teguh Prasetyo dan Abdul Halimah Barkatullah, Politik Hukum Pidana (Kajian Kebijakan Kriminalisasi Dan Dekriminalisasi), (Yogyakarta: Pustaka Pelajar. 2005), hlm. 125

${ }^{3}$ Zainuddin Ali, Hukum Pidana Islam, Cet. II, (Jakarta: Sinar Grafika, 2009), hlm. 12-14
} 
And whoever kills a believer on purpose, his recompense is Hell, he will abide therein and Allah is angry with him, and curses him and prepares a great punishment for him. (Q.S an-Nisa' (4): 93$)^{4}$.

The meaning of "eternal" is to stay for a long time because several arguments explain that the torment of the Muslims who commit immoral acts will not be eternal ${ }^{5}$. Qishash must be carried out as a sanction for intentional killing, attacks that injure bones, or beheading a limb until it is separated from the body.

\section{Human Rights in Islamic Perspective}

In the Big Indonesian Dictionary, human rights are defined as basic rights or basic rights such as the right to life and the right to protection. Human rights according to their nature, which cannot be separated from their essence and therefore are sacred ${ }^{6}$.

The general principles on human rights proclaimed by the General Assembly of the United Nations (UN) in 1948 are considered the standard for implementing human rights enforcement for nations, especially those who have joined the world's highest body until now. . These general principles are known as the Universal Declaration of Human Rights, UDHR (universal statement on human rights $)^{7}$.

Furthermore, human rights which are considered as rights that are brought from the time a person is born into the world are actually a gift from God the Creator (natural rights). Therefore no single power in the world can revoke it. However, according to Bahruddin Lopa, "it does not mean that humans with their rights can act arbitrarily. Because, if someone does something that can be categorized as raping other human rights, then he must be held accountable for his actions. So human rights contain absolute freedom without heeding the rights and interests of others. Therefore, human rights are based on a fundamental basis, namely the right to freedom and the right to equality. From these two bases, other human rights were born ${ }^{8}$.

\footnotetext{
${ }^{4}$ Kementrian Agama RI, AL-Qur'an dan Tajwid, (Jakarta: SYGMA, 2010), hlm. 93.

${ }^{5}$ Wahbah Zuhaili, Fiqh Imam Syafi'I, (Beirut: Darul Fikr, 2008), hlm. 152.

${ }^{6}$ Tim Penyusun Kamus Departemen Pendidikan dan Kebudayaan RI, Kamus Besar Bahasa Indonesia, (Jakarta, 1988), hlm. 292.

${ }^{7}$ Ahmad Kosasih, HAM dalam Perspektif Islam, (Jakarta: Salemba Diniyah, 2003), hlm. 18.

${ }^{8}$ Ahmad Kosasih, HAM dalam Perspektif Islam, hlm. 19.
} 
One of the human rights is the right to life, protection and honor. The UDHR states:

\section{How is the Law of Qishash for a Murderer}

In setting the law, the Imams of the Madhhabs differ in their method. Here will be explained how the steps of taking the inference of qishash punishment:

a. The evidence of the Qur'an

In the Qur'an, there are many verses that explain the prohibition of killing fellow Muslims, including 9 :

Q.S al-An'am (6) verse 151:

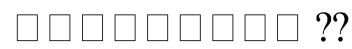

"And do not kill the soul which Allah has forbidden (to kill) except with something (cause) that is true, that is what you are commanded to understand (it). (Q.S al-An'am (6): 151) ${ }^{10}$.

Q.S an-Nisa '(4) verse 93:

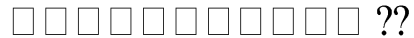

And whoever kills a believer intentionally, his recompense is hell, to abide therein forever, and Allah is angry with him, and curses him and prepares for him a great punishment. (Q.S anNisa '(4): 93).

Qishash is prescribed in the Qur'an and Sunnah as well as ijma '. According to Q.S alBaqarah (2) verse $178^{11}$ :

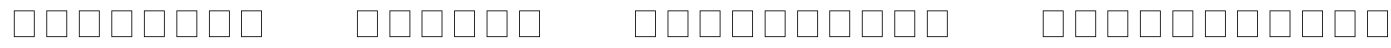

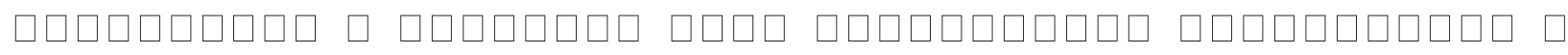

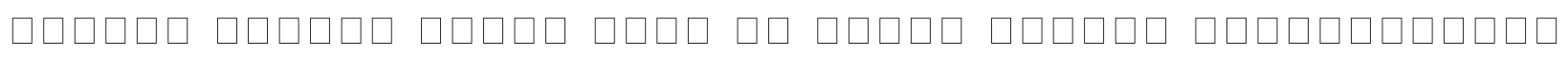

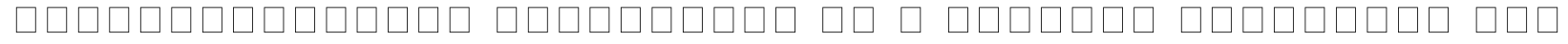

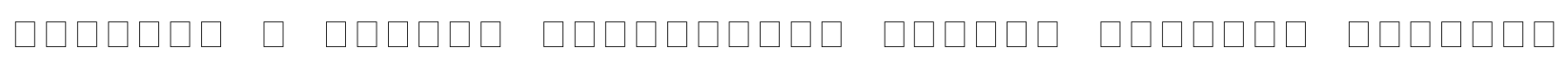

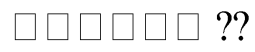

\footnotetext{
${ }^{9}{ }^{9}$ Kementrian Agama RI, AL-Qur'an dan Tajwid, hlm. 146.

${ }^{10}$ Kementrian Agama RI, AL-Qur'an dan Tajwid, hlm. 93.

${ }^{11}$ Kementrian Agama RI, AL-Qur'an dan Tajwid, hlm. 27.
} 
O you who believe, qishaash is obligatory upon you with respect to those who are killed; free man with free man, slave with slave, and woman with woman. So whoever obtains forgiveness from his brother, let (the one who forgives) follow in a good way, and let (the one who is forgiven) pay (diat) to the one who forgives in a good way (also) . that is a relief from your Lord and a mercy. Whoever transgresses after that, for him is a painful punishment. (Q.S al-Baqarah (2): $178)^{12}$.

In Q.S al-Baqarah verse 178, it is explained that the person who kills must be diqishash, but in the next passage, the punishment of qishash for the perpetrator of murder can be replaced by paying diyat to his heirs or family.

\section{b. Hadith of the Prophet}

The second step in inferring the law is to look at the arguments in the hadith of the Prophet. In the hadith it has also been mentioned a lot that killing is unlawful. Among the hadith

In Q.S al-Baqarah verse 178, it is explained that the person who kills must be diqishash, but in the next passage, the punishment of qishash for the perpetrator of murder can be replaced by paying diyat to his heirs or family.

\section{b. Hadith of the Prophet}

Langkah yang kedua dalam pengambilan istinbat hokum adalah melihat dalil-dalil pada hadis Nabi. Di dalam hadis juga telah banyak disebutkan bahwa membunuh itu haram hukumnya. Di antara hadis yang menjelskan pengharaman membunuh yakni hadis yang diriwayatkan oleh Utsman: "Tidak halal membunuh seorang Muslim kecuali salah satu dari tiga sebab; kafir setelah beriman, berzina setelah ,menikah, dan membunuh orang lain tanpa alasan yang benar. (H.R Ahmad bin Hanbal) ${ }^{13}$

12 12Qishaash ialah mengambil pembalasan yang sama. qishash itu tidak dilakukan, bila yang membunuh mendapat kema'afan dari ahli waris yang terbunuh Yaitu dengan membayar diat (ganti rugi) yang wajar. pembayaran diat diminta dengan baik, umpamanya dengan tidak mendesak yang membunuh, dan yang membunuh hendaklah membayarnya dengan baik, umpamanya tidak menangguh-nangguhkannya. bila ahli waris si korban.

${ }^{13}$ Ditakhrij oleh: 1. Imam Bukhari kitab: Diyat, 2. Abu Daud kitab: Hudud, 3. At-Tirmidzi kitab: Diyat, 4. An-Nasa'I kitab: Tahrim ad-Daam, 5. Ibnu Majjah kitab: Hudud. (Imam Nawawi, al-Minhaj Syarh Shahih Muslim Ibn al-Hajjaj, terj. Thoriq Abdul Aziz dan M. Fathoni, (Jakarta: Darus sunnah Press, 2013), hlm. 298). 


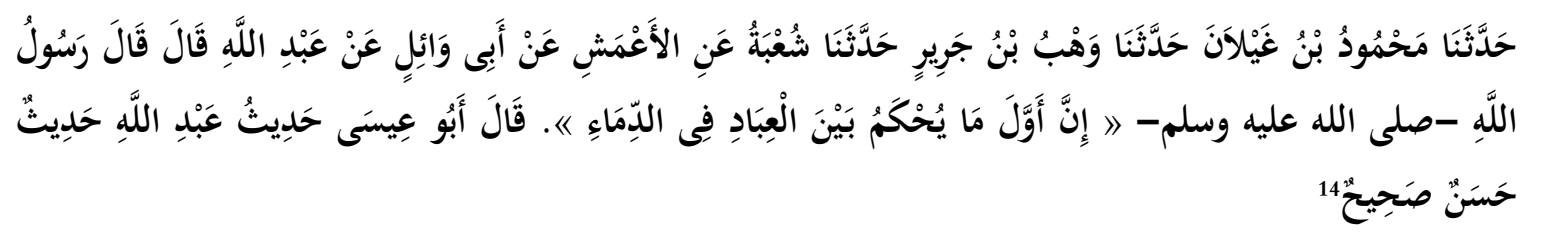

Rasulullah SAW bersabda: perkara pertama kali yang akan diselesaikan di antara manusia pada hari kiamat adalah perkara darah (pembunuh). ${ }^{15}$

Tetapi dalam hadis lain yang diriwayatkan oleh Adu Daud pada bab diyat menjelaskan bahwa "Imam memerintahkan agar memberi pengampunan pada perkara penumpahan darah.

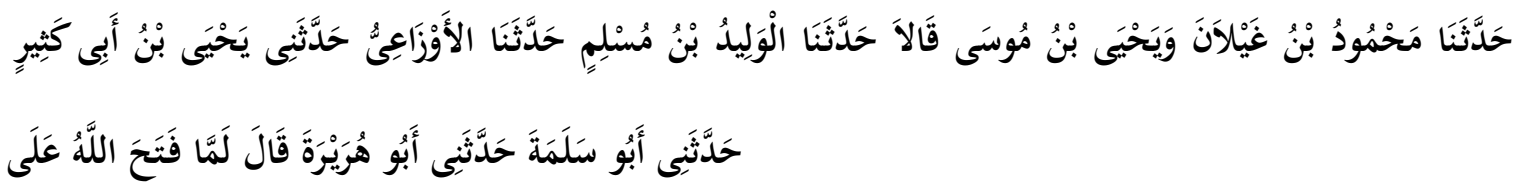

The wicked know what they know and what they do.

Mahmud ibn Ghailan and Yahya ibn Musa narrated to us, they both said, Walid ibn Muslim narrated to us, Yahya ibn Abu Katsir narrated to me, Abu Salimah narrated to me, Abu Hurairah narrated to me, he said: "When Allah liberated the city of Mecca for the Messenger- He, he stood before the people, after praising God, he also said: whoever his family is killed without a justifiable reason, then his guardian can choose between two things, forgive or kill ${ }^{16}$.

From the meaning of the hadiths that have been mentioned above, there is a difference of opinion. Because the status of the two hadiths is authentic, there needs to be a compromise. Jumhur fuqaha 'argues that the merger becomes obligatory when possible. And this combination is better than tarjih (strengthening one hadith over another). If a person has the ability to redeem himself with property, then he is obliged to redeem $i^{17}$. hlm. 430 .

${ }^{14}$ Kamal Yusuf al-Hauti, al-Jami al-Shahih (Sunan at-Turmudzi) juz V, (Beirut: Dar al-Kutub al-Ilmiah, tt),

${ }^{15}$ Ditakhrij oleh: 1. Al-Bukhari kitab Ahadits ar-Riqaq, 2. At-Tirmidzi kitab: Diyat, 3. an-Nasa'I kitab: Tahrim ad-Daam, 4. Ibnu Majjah kitab: Diyat. (Imam Nawawi, al-Minhaj Syarh Shahih Muslim Ibn al-Hajjaj, terj. Thoriq Abdul Aziz dan M. Fathoni, hlm. 306-307.

${ }^{16}$ Kamal Yusuf al-Hauti, al-Jami al-Shahih (Sunan at-Turmudzi) juz V, hlm. 443.

${ }^{17}$ Ibnu Rusyd, Bidayatul Mujtahid, terj. M.A Abdurrahman dan A.Haris Abdullah, (Semarang: asy-Syifa', 1990), hlm. 544. 
This is also confirmed by the hadith narrated by Abu Daud, at-Tirmidhi, asy-Syafi'I, Ahmad, and al-Baihaqi ${ }^{18}$,

$$
\text { يقاد أن و إما ـ الدية يعنى - يعطى أن إما النظرين بخير فهو قتيل له قتل ومن" وسلم عليه الله صلىـ الله رسول قال }
$$
"القتيل أهل

Abu Syuraikh al-Ka'bi narrated, the Prophet SAW said: You Khaza'ah tribe have killed this victim from the tribe of Hudzail, and I am his' Aqilah. Whoever commits murder after this, his family is allowed to choose two things; if you choose the death penalty, kill the perpetrator, and if you choose to grant pardon then take diyat from him. (H.R Abu Daud, at-Tirmidhi, as-Syafi'I, Ahmad, son of al-Baihaqi ${ }^{19}$.

then take diyat from him. (H.R Abu Daud, at-Tirmidhi, as-Syafi'I, Ahmad, son of alBaihaqi $)^{20}$.

4. Ijma,

When one of the wali of the slain person forgives qishash the punishment turns into diyat. The provisions of diyat that have been agreed upon by the mujtahids are explained in number 1868: "diyat of an independent Muslim man, a hundred camels are taken from the property of the killer who deliberately kills, if he is exempted from qishash and pays diyat." Abu Hanifah opined: payment can be delayed for three years ${ }^{21}$.

Abu Hanifah and Malik said in a narration: what must be borne is qishash. In other narrations, can he choose between receiving qishash and diyat. And Asy Syafi'i also argues, that although what is obligatory is only qishash, but it is permissible for those who demand to accept diyat even if it is not liked by those who do wrong ${ }^{22}$.

As for the benefit of the misunderstanding here is: if the saint who was killed forgives, the diyat falls away. And if the wali forgives qishash only, then diyat is imposed even if the killer does hlm. 154 .

${ }^{18}$ Imam Nawawi, al-Minhaj Syarh Shahih Muslim Ibn al-Hajjaj, terj. Thoriq Abdul Aziz dan M. Fathoni,

${ }^{19}$ Abi Daud Sulaiman, Sunan Abi Daud Juz VIII, (Beirut: Darul Kitab al-'Ilmiah, 1996), hlm. 480.

${ }^{20}$ Wahbah Zuhaili, Fiqh Imam Syafi'I, (Beirut: Darul Fikr, 2008), hlm. 182.

${ }^{21}$ Dalam madzab imam Syafi'i diyat itu dibagi menjadi dua: diyat mugholadoh (diyat yang diberatkan yaitu diyat pembunuhan yang sengaja dan yang diserupakan dengan itu. Kedua, Diyat mukhaffafah (diyat yang diringankan yaitu diyat pembunuhan yang tidak disengaja).

22 Teungku Muhammad Hasbi ash-Shiddieqy, Hukum-Hukum Fiqh Islam Tinjauan antar Madzab, (Semarang: PT Pustaka Rizki Putra, 2001), hlm. 452-453. 
not like it. According to Abu Hanifah's understanding: diyat cannot be claimed if it is not diridhoi by the killer. As-Syafi'i and Ahmad allow. From Malik received two narrations.

Paying diyat in retaliation for murder was also confirmed by al-Baihaqi who narrated from a mujahid: "The Shari'ah of the Prophet Moses strictly obligates the punishment of qishash, while the Shari'ah of the Prophet Jesus only obligates.

qishas punishment is strict, while the shari'ah of Prophet Jesus only requires diyat, then Allah makes it easy for this ummah to choose one of them.

5. Determination of Law based on Maslahah Mursalah

Judging from the maslahah mursalah, the appropriate punishment for the murderer is diyat. The standard of justice in the application of absolute punishment is to adjust the will of the community and at the same time consider the form, quality and quantity of the crime committed. Whereas the law in the sense that it is a formal one, then in this case the emphasis is more on the function of determining punishment, meaning that the application of absolute punishment is sought as an effort to realize justice.

\section{CONCLUSION}

In Indonesia, human rights are highly respected, related to human rights, the diyat punishment can replace the qishosh punishment. This is in accordance with the purpose of human rights, namely protecting one's soul and it is also in accordance with the socio-cultural nature of the Indonesian people, which are mostly gentle and compassionate ${ }^{23}$. If the perpetrator of the murder has a small child, for example, this is also a consideration for forgiveness or a substitute in the form of diyat. Because if the qishash punishment is carried out it will make the child and his family neglected. Thus the law of qishash is associated with human rights and socio-cultural Indonesian society. Then qishosh can be replaced with diyat. Thus the explanation that the author can convey, given the limited knowledge and skills possessed. The author apologizes profusely.

\section{DAFTAR PUSTAKA}

Abi Daud Sulaiman, Sunan Abi Daud Juz VIII, Beirut: Darul Kitab al-‘Ilmiah, 1996.

${ }^{23}{ }^{23}$ Wahbah Zuhaili, Fiqh Imam Syafi'I, hlm. 184. 
Ali, Zainuddin, Hukum Pidana Islam, Cet. II, Jakarta: Sinar Grafika, 2009.

Haliman, Hukum Pidana Syari'at Islam Menurut Ahlus Sunnah, Jakarta: Bulan Bintang. 1970.

Hasbi ash-Shiddieqy, Muhammad, Hukum-Hukum Fiqh Islam Tinjauan antar Madzab, Semarang: PT Pustaka Rizki Putra, 2001.

Ibnu Rusyd, Bidayatul Mujtahid, terj. M.A Abdurrahman dan A.Haris Abdullah, Semarang: asySyifa', 1990.

Imam Nawawi, al-Minhaj Syarh Shahih Muslim Ibn al-Hajjaj, terj. Thoriq Abdul Aziz dan M. Fathoni, Jakarta: Darus sunnah Press, 2013.

Kementrian Agama RI, AL-Qur'an dan Tajwid, Jakarta: SYGMA, 2010.

Kosasih, Ahmad, HAM dalam Perspektif Islam, Jakarta: Salemba Diniyah, 2003.

Prasetyo, Teguh dan Abdul Halimah Barkatullah, Politik Hukum Pidana (Kajian Kebijakan Kriminalisasi Dan Dekriminalisasi), Yogyakarta: Pustaka Pelajar. 2005.

Tim Penyusun Kamus Departemen Pendidikan dan Kebudayaan RI, Kamus Besar Bahasa Indonesia, Jakarta, 1988.

Yusuf al-Hauti, Kamal, al-Jami al-Shahih (Sunan at-Turmudzi) juz V, Beirut: Dar al-Kutub alIlmiah, tt.

Zuhaili, Wahbah, Fiqh Imam Syafi'I, Beirut: Darul Fikr, 2008. 